\title{
Urban mobility transitions through GDP growth: Policy choices facing cities in developing countries
}

\author{
Roger Teoh \\ Imperial College London, United Kingdom \\ Paulo Anciaes \\ University College London, United Kingdom \\ Peter Jones \\ University College London, United Kingdom
}

Published in Journal of Transport Geography 88:02832

\begin{abstract}
This paper analyses the factors associated with the private transport modal share in cities of different wealth. We use the 1995 UITP Millennium Cities dataset and smaller samples of matching cities in the 2012 UITP Mobility in Cities dataset. Segmented bivariate analysis using the 1995 data showed that the associations between the private transport share and various socio-economic, transport, and land use variables are mostly non-linear or moderated by third variables. K-means clustering of the same 1995 variables then revealed three distinct groups of cities. Cluster 1 contains cities in developing countries with low private transport share and poor provision for both private and public transport. Cluster 2 contains highincome cities with high private transport share, low population density, and better relative provision and quality of private transport. Cluster 3 also contains high-income cities but with a moderate private transport share, higher population density, and better relative provision and quality of public transport. The evolution of cities from 1995 to 2012 showed that, as cities grow in wealth, they either move from Cluster 1 to Cluster 2 or from Cluster 1 to Cluster 3. Regression analysis provided further confirmation that the private transport share is explained by the variables that define the three clusters. Overall, the paper provides information for cities in developing countries to formulate combinations of transport and land use policies that can contribute to a transition towards sustainable transport systems.
\end{abstract}

Keywords: Sustainable cities, urban transport, travel mode share, car dependence; transport policy, development pathways 


\section{Introduction}

The invention and commercialisation of motorised vehicles revolutionised not only the transport sector but also the way that cities are shaped and planned. Throughout most of the $20^{\text {th }}$ century, city planning in Western Europe and North America mainly revolved around accommodating an ever-growing use of private cars. This involved expanding or upgrading roads and car parking infrastructure, together with decentralised patterns of urban development. However, the increased use of private cars had negative consequences such as congestion, traffic collisions, sedentary lifestyles, poor-quality street environments, noise, air pollution, and the emission of greenhouse gases (Banister, 2011; Harrington \& McConnell, 2003; Nicolopoulou-Stamati et al., 2005). For this reason, the paradigm underlying urban transport policy in many cities has been changing. Larger cities in Western Europe typically follow a 3-stage process, with the focus shifting first from moving vehicles to moving people, and then to improving urban quality of life (Figure 1). This latter focus involves policies to: (i) restrain car traffic; (ii) improve public transport and conditions for walking and cycling; and (iii) enhance the use of streets as public places (Jones et al., 2018). This paradigm change is associated with changes in travel behaviour from a rapid growth to a levelling off and eventually a decline in the private transport modal share (the proportion of private transport in all daily trips).

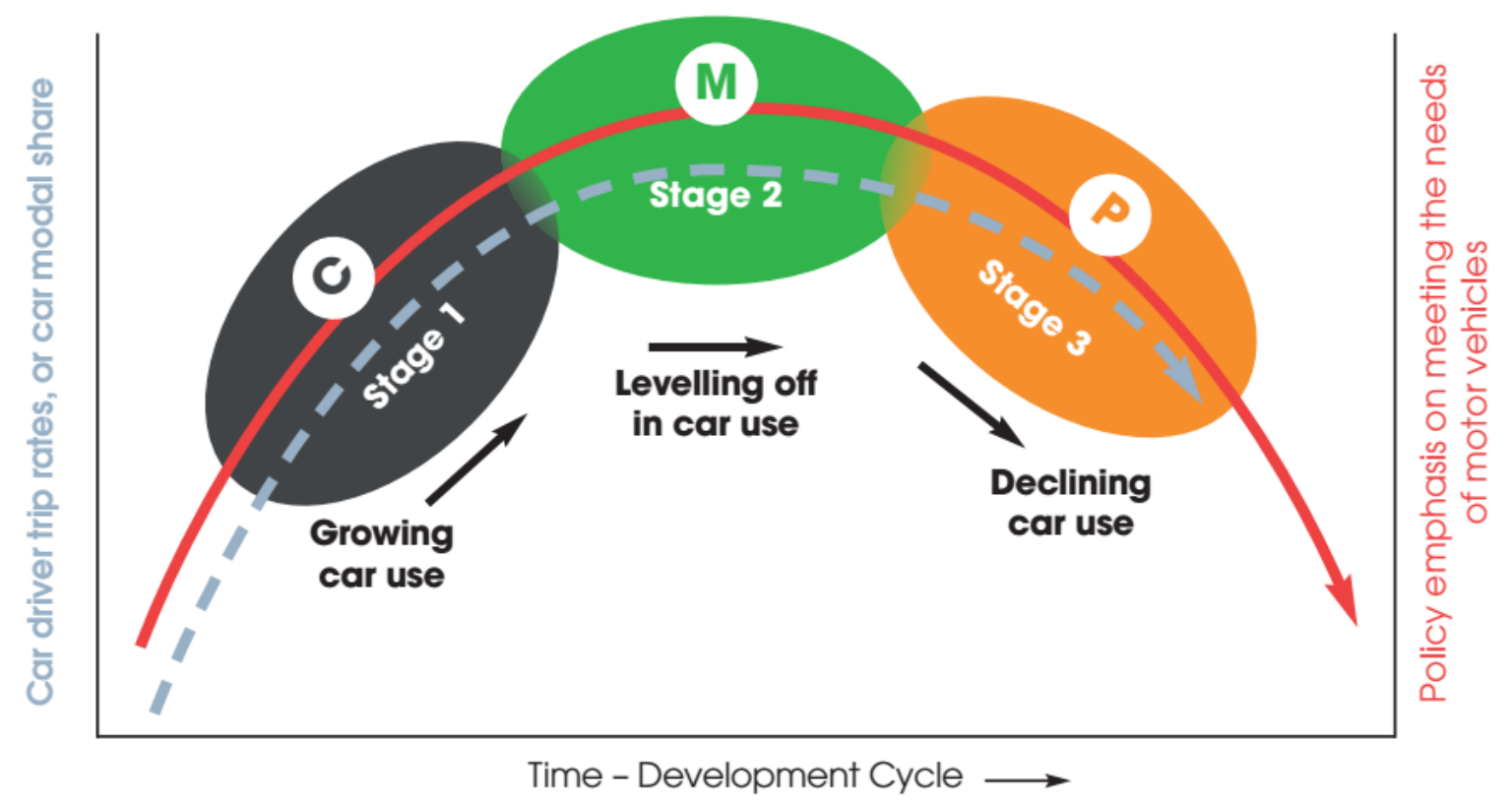

Notes: C: "Car-oriented City", M: "Sustainable Mobility City", P: "City of Places"

Figure 1: Typical '3-stage' urban transport policy development process (Source: Jones et al. (2018), reproduced with permission). 
While it is evident that many Western European cities have undergone this 3-stage process (Buehler et al., 2017; Halpern et al., 2018), car use has continued to grow in other cities with similar income levels (such as in North America or the Gulf region), where transport policy still favours a car-centric paradigm (Alotaibi \& Potoglou, 2017; Buehler, 2009). This is because, over time, the modification of transport infrastructure and land use patterns can result in private vehicles being the only feasible mode of transport (Illich, 1974; Briggs et al., 2015; Newman \& Kenworthy, 1989).

Cities in developing countries that are currently experiencing rapid economic growth and increasing car ownership rates from a low base are at a bifurcation point. One possible pathway is to apply the car-oriented transport policies that were adopted by cities in developed countries during the 20th century. The other pathway is to promote the transport policies that are currently favoured in some of those cities (in particular, Western European cities), focusing on sustainability and quality of life. At the same time, there is a urgent need to apply policies that reduce the negative impacts of car use, which are already growing fast in cities in developing countries (Pojani \& Stead, 2017).

This paper aims to understand the factors that are related to the private transport modal share in cities of different wealth, including the socio-economic context, the characteristics of private and public transport systems, and urban land use. This allow us to identify the pathways that cities have followed in the past and the combinations of policies that might be used in cities in developing countries to contain the growth of the private transport share in the future.

We use datasets published by the International Association of Public Transport (UITP), covering the years of 1995 and 2012. The 1995 dataset has been used in previous studies in this field (Cameron et al., 2003; Kenworthy \& Laube, 1999 2002a, 2002b). However, there is a strong case for revisiting it in light of the trends that have been identified for the period since 1995, such as the "peak car" phenomenon that was observed in many cities in developed countries (Goodwin \& Van Dender, 2013; ITF, 2013; Metz, 2013). We use the larger 1995 data to explain differences in the private transport share across cities and, where possible, examine if the changes from 1995 to 2012 are consistent with the cross-sectional patterns. 


\section{Private transport modal share in cities: main evidence and an unanswered question}

The literature produced in the past two decades revealed four groups of factors that can explain the differences in the private transport modal shares across cities: (i) socio-economic factors; (ii) the characteristics of the private transport system; (iii) the characteristics of the public transport systems; and (iv) land use patterns. Figure 2 synthesizes the existing evidence, highlighting the factors that have been related to the private transport share at the city level (brown rectangles) and the main inter-relationships between these factors (dotted lines). It should be noted that the figure is a simplified representation of the relationships between the four groups of factors and the private transport share. In most cases, these relationships are mediated by changes in travel behaviour and occur with some time lag. The following subsections review the evidence on the four groups of factors.

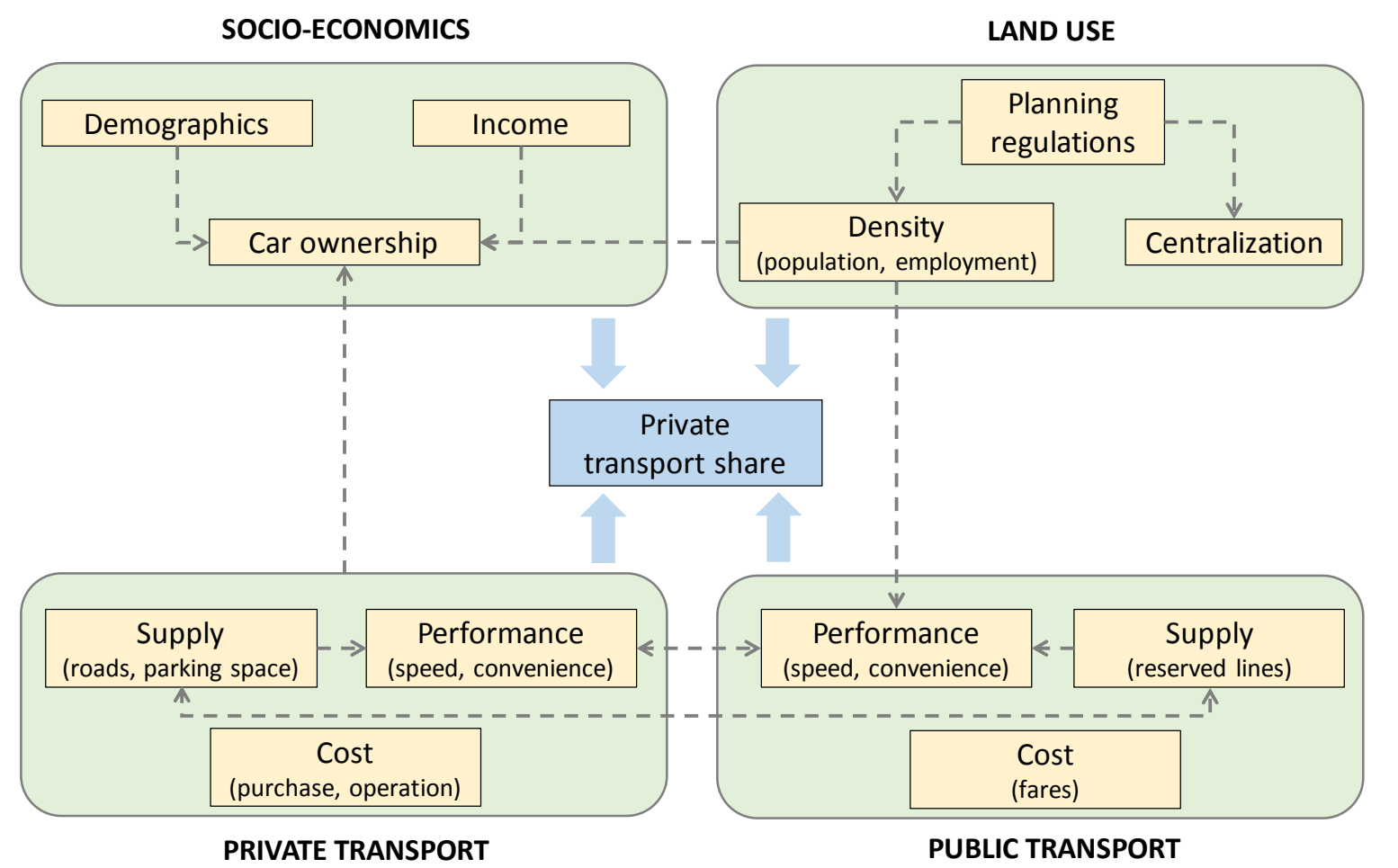

Figure 2: Summary of evidence on the factors affecting the private transport mode share at the city level

\subsection{Socio-economic factors}

Income tends to be a strong predictor of the private transport share at the city level, with cross-sectional studies often finding that higher incomes are associated with higher private transport shares (Ahmad \& Oliveira, 2016; Santos et al., 2013). A time-series study found 
that this pattern also applied over time during the period of 1960-1990 (Schafer, 1998). However, these findings do not explain why cities such as Copenhagen, Hong Kong, and Singapore have a high average income but a relatively low private transport share (Cullinane, 2002; Gössling, 2013; Han, 2010). In addition, recent time-series data suggest that higher income has a progressively decreasing impact on car use. For example, Newman and Kenworthy (2015) showed that car-kilometres per gross domestic product (GDP) in 39 out of 42 'global cities' decreased between 1995 and 2005, even though income increased in all those cities during this period.

The positive association between the private transport share and income levels can partially be explained by the mediating effect of car ownership. In general, car use increases with car ownership, and car ownership increases with income (Cameron et al., 2004; Dargay \& Gately, 1999; Li et al., 2010; Santos et al., 2013). However, cities with the same car ownership rates often have very different private transport shares. For example, Buehler (2011) showed that the private transport shares in US cities are, on average, $25 \%$ higher than those of German cities, despite having comparable car ownership rates. This may be explained by the influence of other variables, such as population density. Higher densities tend to result in less attractive conditions for car use and increase the financial viability of public transport, thus providing an incentive for individuals to use their cars less often (Guerra \& Cervero, 2011; Newman \& Kenworthy, 2015).

The private transport share is also influenced by demographic factors such as the proportion of the population in employment (Van de Coevering \& Schwanen, 2006) and the proportion of students, elderly, and households without children (Santos et al., 2013). In some cities in developed countries, recent declines in absolute and relative levels of car use may also be explained by the shift towards more flexible employment and activity patterns and an increased preference for sustainable lifestyles (Delbosc \& Currie, 2013; Garikapati et al., 2016; Hopkins, 2016).

\subsection{Characteristics of private and public transport}

The private transport share also depends on the provisions made for the different modes of transport, i.e. the availability of infrastructure for use of those modes. There is some consensus that building roads and increasing the supply of car parking spaces tend to increase car use due to an "induced demand" effect (Cervero, 2003; Noland \& Lem, 2002). The same rationale may apply to the alternatives to car use. For example, cities with public transport 
modes with a dedicated-right-of-way, such as railways and metro systems, tend to have higher public transport use (Ingvardson \& Nielsen, 2018) and lower car use (McIntosh et al., 2014). Household proximity to public transport is also related to higher public transport shares (Buehler, 2011). In contrast, cities that neglect public transport, walking, and cycling infrastructures tend to have higher levels of car use (Tiwari et al., 2016).

The absolute and relative levels of public transport use are also related to the level of supply of public transport, as measured by the total length of services per capita (McIntosh et al., 2014) and the number of vehicles in operation (Santos et al., 2013). They are also related with the relative performance of public transport, compared with private transport, as measured by door-to-door travel speeds (Kenworthy \& Laube, 2002a).

Cost factors are also relevant. It is often argued that the cost of using private cars does not include the negative externalities on society, such as congestion and pollution, leading to a higher than optimal levels of car use (Briggs et al., 2015). Policies that increase the cost of using a private car (e.g. road pricing, parking fees) can reduce car use (Buehler et al., 2017), while policies that increase the cost of purchasing a car (e.g. vehicle taxation schemes) can reduce car ownership (Cullinane, 2003; Newman \& Kenworthy, 2015). In the same vein, subsidies to reduce the cost of using public transport can lead to a shift to public transport (Basso \& Silva, 2014).

Nevertheless, expanding the public transport infrastructure and supply, improving performance, and reducing the cost of public transport services, may not be enough to reduce the private transport share. This is because public transport trips are not a perfect substitute for car trips. More and better public transport may simply redistribute demand between public transport modes (Younes, 1995) or capture demand from non-motorised modes.

\subsection{Land use}

The private transport share in cities is also closely related to patterns of land use. Several studies have shown that cities with a higher population and/or job density tend to have lower levels of car use (Newman \& Kenworthy, 1989; 1999; 2015) and higher public transport shares (Ahmad \& Oliveira, 2016; Buehler, 2011; Schwanen, 2002). This may be because lower densities increase the travel times by public transport (when compared with private transport) and decrease the financial viability of public transport systems (Guerra \& Cervero, 2011; Newman \& Kenworthy, 2015). In contrast, higher densities may reduce the attractiveness of car travel due to congestion and constraints on car parking. Land use 
centrality, as measured by the proportion of population and/or jobs in the city centre, is also associated with higher public transport shares (Schwanen, 2002; van de Coevering \& Schwanen, 2006). City shape may also be relevant, although there is little empirical evidence on the significance of this factor in explaining differences in modal shares across cities.

It is likely that the associations between the private transport share and land use factors (i.e. population, job density and centrality) are mediated by car ownership levels (Karathodorou et al., 2010; Van Acker \& Witlox, 2010). Those associations also depend on the housing and urban development history of each city. For example, Van de Coevering \& Schwanen (2006) found that the private car share in some European and North American cities was negatively associated with the share of rental dwellings and dwellings built before World War II. Land use regulations, such as zoning of different activities, may also be relevant. However, no studies to date have included indicators of the strength or the nature of these regulations in models explaining the private transport share at the city level.

\subsection{Unanswered question: why different pathways for the modal share as income grows?}

As evident in the previous subsections, the private transport modal share in cities depends on a complex mix of transport and non-transport factors. However, despite the evidence on each of these factors, there is still a gap in knowledge about the evolution of the private transport share as city income grows, i.e. the combination of factors that result in some cities continually increasing the share of private transport trips, while others stabilize this share and eventually reduce it. Our paper delves into this question by looking at the similarities and differences between cities in terms of the relationship between the private transport share and each of the factors reviewed in this section.

\section{Data and methods}

The main dataset used in this paper is the UITP Millennium Cities Database for Sustainable Transport 1995 (Kenworthy \& Laube, 2001). This dataset, hereafter named UITP 1995, is one of the most comprehensive datasets available (Kenworthy \& Laube, 2002b; Kenworthy, 2014), and includes 230 variables for 100 cities. We focus on the UITP 1995 dataset and not on the more recent datasets in the same series, the 2001 and 2012 UITP Mobility in Cities Databases (UITP 2001 and UITP 2012) for two reasons related to the hypothesis of the paper. 
Firstly, the UITP 2001 and UITP 2012 datasets contain fewer variables, more missing values, and fewer cities, with an underrepresentation of cities in North America and developing countries. Given the hypothesis of the paper that cities may follow different pathways in terms of private transport share as their income grows, it is crucial that the dataset includes: (i) cities at different income levels (including cities in developing countries); and (ii) cities with similar income levels and different levels of car use (for example European vs. North American cities). Only the UITP 1995 dataset has these two features.

Secondly, the UITP 1995 dataset provides information about a moment relatively distant in the past, which, for the purposes of this paper, is an advantage rather than a disadvantage. This is because the pathways implicit in 1995 cross-sectional patterns can be validated against the observed pathways followed by cities in the years that followed. This is done throughout the paper by comparing the pathways implicit in the UITP 1995 data with the evolution of a group of cities from 1995 to 2012, using UITP 2012 data.

Our sample of the UITP 1995 dataset includes 84 cities out of the 100 that are available. The remaining 16 cities were excluded because they had missing values in at least one of the variables selected for analysis. The sample account for cities from all regions, including Western Europe (32 cities), Eastern Europe (3), Middle East (3), Asia (17), North Africa (2), Sub-Saharan Africa (4), North America (15), Latin America (3), and Oceania (5). As cities in Latin America, Africa, and parts of Asia were under-represented in the UITP 1995 dataset, the implications of factors that are unique to those regions (e.g. the development of bus rapid transit systems in Latin America) is not embedded in our analysis. As noted above, the UITP 2012 dataset is smaller and has more missing data. Therefore, the set of cities used from this dataset varies in each analysis, as will be described in subsequent sections.

The key variable is the proportion of daily trips made by private motorised modes (car and motorcycle) in each city, both as a driver and a passenger, named henceforth as the private transport share. This is the most appropriate variable for the purposes of this paper, as it is an indicator of the relative intensity of private motorised transport use in relation to other modes (public motorised transport and non-motorised modes). This is in contrast with variables measuring only the absolute intensity of private transport use, such as the per-capita vehicle$\mathrm{km}$ travelled by car. In the UITP 1995 dataset, the private transport share has a mean of 53\% and a standard deviation of 23\%, varying from 7\% (Shanghai) to 97\% (Riyadh). 
We related the private transport share with 11 explanatory variables (Table 1) that were identified as relevant in the literature review (Section 2), accounting for socio-economic, transport, and land use factors. These variables were either extracted directly or derived from the UITP datasets. GDP per capita was taken as an indicator of the average income in each city. Details about the methods used to collect the data and define these variables can be found in Kenworthy and Laube (2002b). The means and standard deviations of these variables in the UITP 1995 sample are reported in Table 1.

Table 1: Variables hypothesized to be related to private transport share: list and descriptive statistics

\begin{tabular}{|c|c|c|c|}
\hline $\begin{array}{c}\text { Factors identified } \\
\text { in the literature } \\
\text { review }\end{array}$ & $\begin{array}{l}\text { Variables used in } \\
\text { the paper }\end{array}$ & $\begin{array}{c}\text { Mean } \\
\text { (UITP 1995) }\end{array}$ & $\begin{array}{c}\begin{array}{c}\text { Standard } \\
\text { deviation } \\
\text { (UITP 1995) }\end{array} \\
\end{array}$ \\
\hline \multirow{2}{*}{ Socio-economic } & Metropolitan GDP per capita (1000 US\$) & 21.9 & 14.9 \\
\hline & Number of passenger cars per capita & 0.39 & 0.18 \\
\hline \multirow{2}{*}{$\begin{array}{l}\text { Provision for } \\
\text { private transport }\end{array}$} & Length of freeways per capita (metres) & 0.07 & 0.06 \\
\hline & Parking spaces per CBD job & 0.29 & 0.30 \\
\hline \multirow{2}{*}{$\begin{array}{l}\text { Provision for } \\
\text { public } \\
\text { transport }\end{array}$} & $\begin{array}{l}\text { Length of reserved public transport routes per capita } \\
\text { (metres) }\end{array}$ & 0.11 & 0.13 \\
\hline & Public transport seat-km of service per capita & 3442 & 2276 \\
\hline \multirow{3}{*}{$\begin{array}{l}\text { Relative quality } \\
\text { and cost of public } \\
\text { versus } \\
\text { private transport }\end{array}$} & $\begin{array}{l}\text { Investment ratio (overall public transport vs. road } \\
\text { network) }\end{array}$ & 0.88 & 1.90 \\
\hline & $\begin{array}{l}\text { Speed ratio (overall public transport vs. road } \\
\text { network) }\end{array}$ & 0.75 & 0.21 \\
\hline & $\begin{array}{l}\text { User cost ratio (public transport vs. car trips per } \\
\text { passenger-km) }\end{array}$ & 0.32 & 0.21 \\
\hline \multirow{2}{*}{ Land use } & Population density (people $\left./ \mathrm{km}^{2}\right)$ & 7503 & 7520 \\
\hline & Proportion of jobs in the CBD (\%) & 18.2 & 11.6 \\
\hline
\end{tabular}

Notes: Reserved public transport includes bus lanes, minibus reserved routes, segregated trams, light rail, metro, suburban rail, and ferry networks. GDP: Gross Domestic Product; CBD: Central Business District.

We acknowledge that the UITP datasets do not include some variables that might also be related with the private transport share, such as (i) socio-economic factors other than income and car ownership, (ii) availability and quality of the infrastructure for walking and cycling, and (iii) indicators of governance structures and party-political dynamics. Alternative data sources could be used to account for some of these variables and to increase the sample size of the UITP datasets. However, we opted not to use those data sources because the definitions of urban area boundaries vary across data sources and the methods to calculate some variables can be inconsistent with those in the UITP datasets.

The analysis consisted of three stages. In the first stage (Section 4), we looked at bivariate associations between the private transport share and the 11 explanatory variables. In some cases, the associations were estimated separately in two segments of the sample, i.e. in cities 
with values above or below a certain cut-off point value of a third variable (population density or car ownership). For each explanatory variable, the cut-off value of the third variable maximises the sum of $\mathrm{R}^{2}$ values between the private transport share and the explanatory variable in the two segments. Where data were available, we also compared the 1995 and 2012 datasets to examine whether the 1995 cross-sectional associations hold over time.

In the second stage (Section 5), we used cluster analysis to classify cities into groups, to identify the characteristics that are associated with different levels of the private transport share in 1995. These results were further validated by looking at the 1995-2012 evolution of income and private transport shares in cities of different clusters.

In the final stage (Section 6), we used regression analysis to test the statistical significance of the variables explaining the private transport share across the whole sample and within each cluster.

\section{Factors influencing the private transport share in cities: segmented bivariate analysis}

\subsection{Socio-economic factors}

There is an 'inverted U'-shaped relationship between the private transport share and income (as measured by GDP per capita) in the UITP 1995 dataset (Figure 3). The private transport share starts growing with higher levels of GDP per capita, peaks at an average level of GDP per capita of around US\$30,000 and then declines among higher-income cities. This crosssectional relationship is consistent with the postulated '3-stage' urban transport policy development process (Figure 1) and with the 'peak car' hypothesis mentioned in Section 1. 


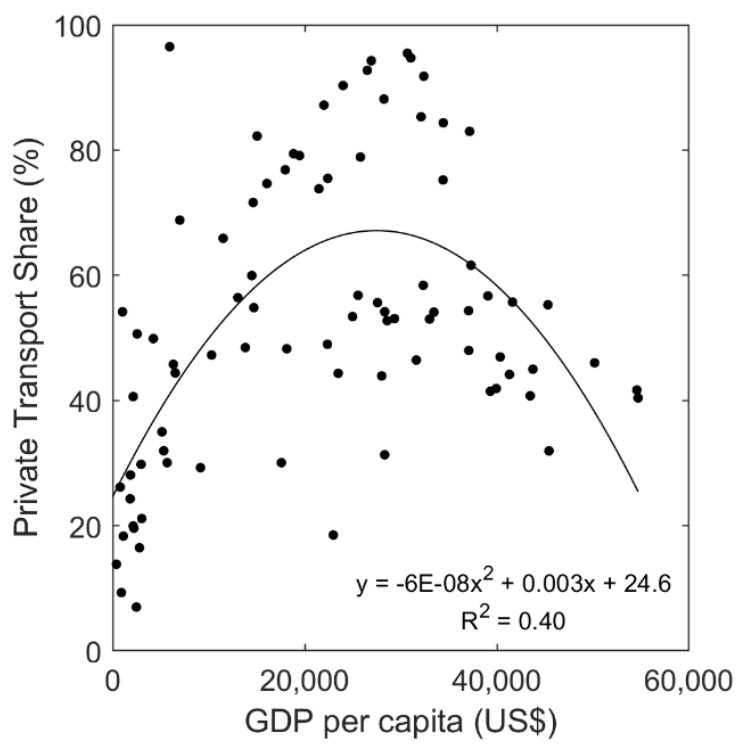

Figure 3: Private transport share vs. GDP per capita (1995)

A comparison of the 1995 and 2012 data suggests that this cross-sectional relationship also applies across time. We investigated this question by splitting the 26 cities with data available on both variables for both years into two segments: middle and high income, i.e. below and above US\$9,385 per capita in 1995. This is the value suggested by the World Bank to separate middle and high-income economies (World Bank, 1997). We found that the seven middle-income cities experienced an increase in the private transport share from an average of $29.8 \%$ in 1995 to $36.1 \%$ in 2012 . In contrast, the 19 high-income cities experienced a reduction from an average of $52.0 \%$ in 1995 to $45.2 \%$ in 2012.

We have also found a positive linear association between the private transport share and the number of passenger cars per capita $\left(\mathrm{R}^{2}=0.50\right)$. To test the hypothesis, mentioned in Subsection 2.1, that this association is moderated by population density, we split the sample into two segments: 'high-density' $\left(\geq 3500\right.$ people $\left./ \mathrm{km}^{2}\right)$ and 'low-density' $\left(<3500\right.$ people $\left./ \mathrm{km}^{2}\right)$. The cut-off point of 3500 people $/ \mathrm{km}^{2}$ maximizes the sum of the two $\mathrm{R}^{2}$ values of the relationships between the private transport share and the number of passenger cars per capita in the two segments. Figure 4 shows a strong linear association between private transport share and the number of passenger cars per capita $\left(\mathrm{R}^{2}=0.86\right)$ in low-density cities but a much weaker one in high-density cities $\left(\mathrm{R}^{2}=0.24\right)$. This suggests that population density does interact with car ownership in determining levels of car use. It is worth noting that the cut-off point of 3500 people $/ \mathrm{km}^{2}$ to segment cities into high- and low-density is also the value that Newman and Kenworthy (2015) identified as the minimum value for urban public transit services to be viable. This supports the hypothesis that population density influences car 
ownership and use via the impact on the viability of public transport, thus providing options for individuals to use their cars less often.

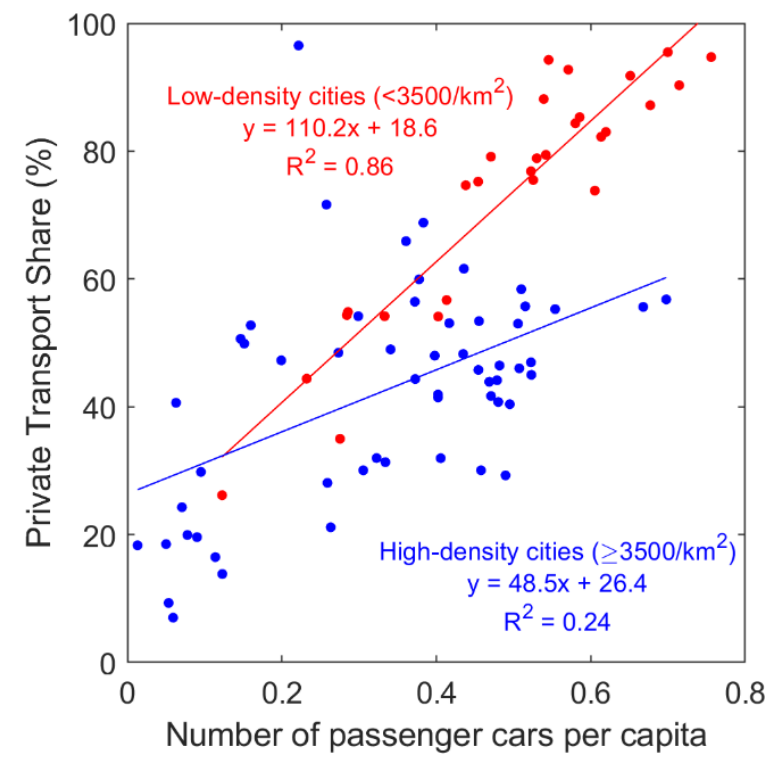

Figure 4: Private transport share vs. car ownership, segmented by population density (1995)

\subsection{Provision for private transport}

Figure 5 shows that the private transport share has: (i) a positive linear relationship with the length of freeways per capita $\left(\mathrm{R}^{2}=0.51\right)$; and (ii) a logarithmic relationship with parking spaces per $\mathrm{CBD}$ job $\left(\mathrm{R}^{2}=0.43\right)$. These results are consistent with the hypothesis of "induced demand" for private transport (see Section 2.2). Segmenting the relationships according to the values of possible moderating variables (for example, car ownership and population density) does not produce stronger relationships in any segment.

The evolution of cities from 1995 to 2012 does not show such clear patterns. Among the 25 cities with data on both variables for both years, the eight cities that decreased their freeway supply did reduce their private transport share (average of $-7.8 \%$ ), which is consistent with the pattern in Figure 5. However, the 17 cities that increased their freeway supply also showed a reduction in their private transport share, albeit at a smaller magnitude (average of 4.5\%). This could be because all except one of these 17 cities were high-income in 2012, and so the income effect shown in the previous subsection (i.e. private transport share starting to decrease after a certain income level) may offset the effect of better provision for private transport. No data was available for the parking space per CBD job variable in 2012. 

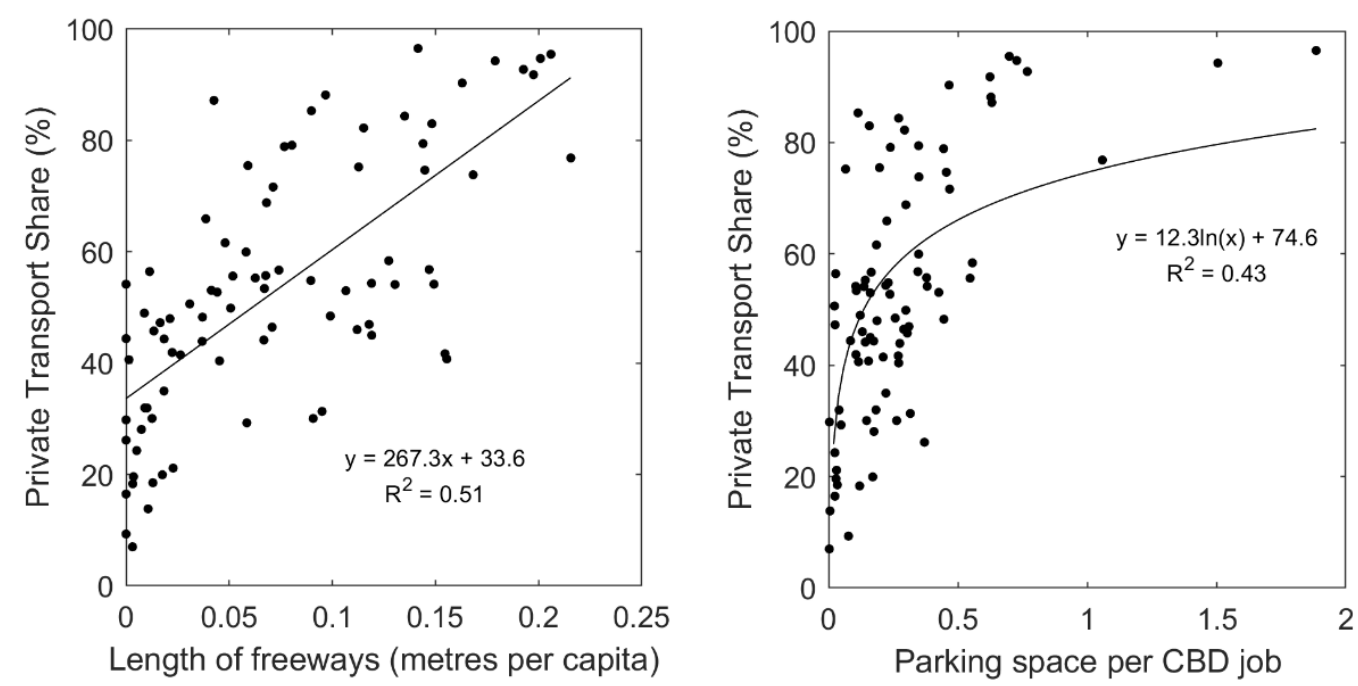

Figure 5: Private transport share vs. provision for private transport (1995)

\subsection{Provision for public transport}

Across the whole sample, we found that the private transport share has a weak negative linear relationship $\left(\mathrm{R}^{2}=0.11\right)$ with the supply of public transport (as measured by public transport seat-km of service per capita). To investigate if the relationship is mediated by population density, we split the sample into low-density and high-density cities, using a cut-off value of 3400 people $/ \mathrm{km}^{2}$. This cut-off value maximizes the sum of the two $\mathrm{R}^{2}$ values of the relationships between the private transport share and seats-km of service per capita in the two segments. We found a strong negative linear association $\left(\mathrm{R}^{2}=0.68\right)$ in cities with low density but not in cities with high density $\left(\mathrm{R}^{2}=0.03\right.$ ) (Figure 6 ). This could be because public transport modes in high-density cities are in competition not only with private transport but also with non-motorised modes, as trip distances tend to be relatively short. An increase in public transport supply may then lead to a redistribution in demand between public transport and non-motorised modes, and not to a reduction of the private transport share (as mentioned in Section 2.2). Conversely, an increase in public transport supply in low-density cities (where trip distances tend to be longer) may have a greater effect in improving the attractiveness of public transport and reducing the private transport share. 


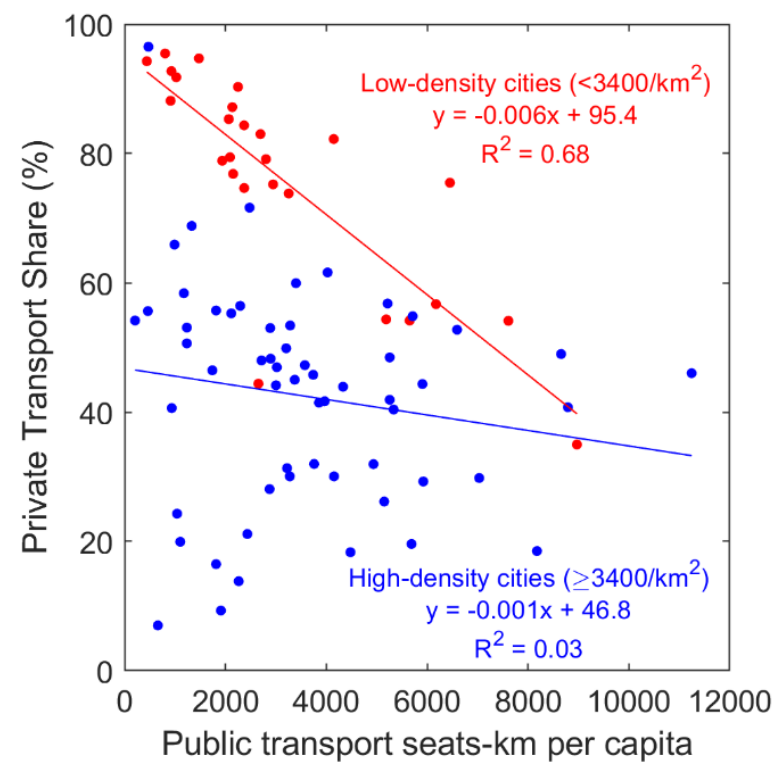

Figure 6: Private transport share vs. public transport seats-km per capita (1995)

A similar conclusion can be derived from the relationship between the private transport share and the length of reserved public transport routes per capita (not shown in Figure 6). Although there is no relationship over the whole sample $\left(\mathrm{R}^{2}=0.005\right)$, a segmentation of the sample into low and high population density (using a cut-off value of 2400 people $/ \mathrm{km}^{2}$, based on the summed $\mathrm{R}^{2}$ criterion) reveals a strong relationship among low-density cities $\left(\mathrm{R}^{2}=0.78\right)$ but not in high-density cities $\left(\mathrm{R}^{2}=0.003\right)$.

\subsection{Relative quality and cost of public and private transport}

There are only weak relationships between the private transport share and (i) the ratio of investment in public transport vs. the road network $\left(\mathrm{R}^{2}=0.06\right)$; (ii) the ratio of overall public transport vs. road speed $\left(\mathrm{R}^{2}=0.14\right)$; and (iii) the ratio of user costs for public transport and car trips $\left(\mathrm{R}^{2}=0.17\right)$.

To test the hypothesis that the association between the private transport share and the relative public transport speed is moderated by car ownership rates, we segmented the sample into high and low car ownership. We used a cut-off point of 0.49 vehicles per capita, which was estimated with the summed $\mathrm{R}^{2}$ criterion. We found a negative linear association between the private transport share and the ratio of overall public transport speed vs. road speed in high car ownership cities $\left(\mathrm{R}^{2}=0.51\right)$, but not in cities with low car ownership $\left(\mathrm{R}^{2}=0.01\right)$ (Figure 7$)$. 


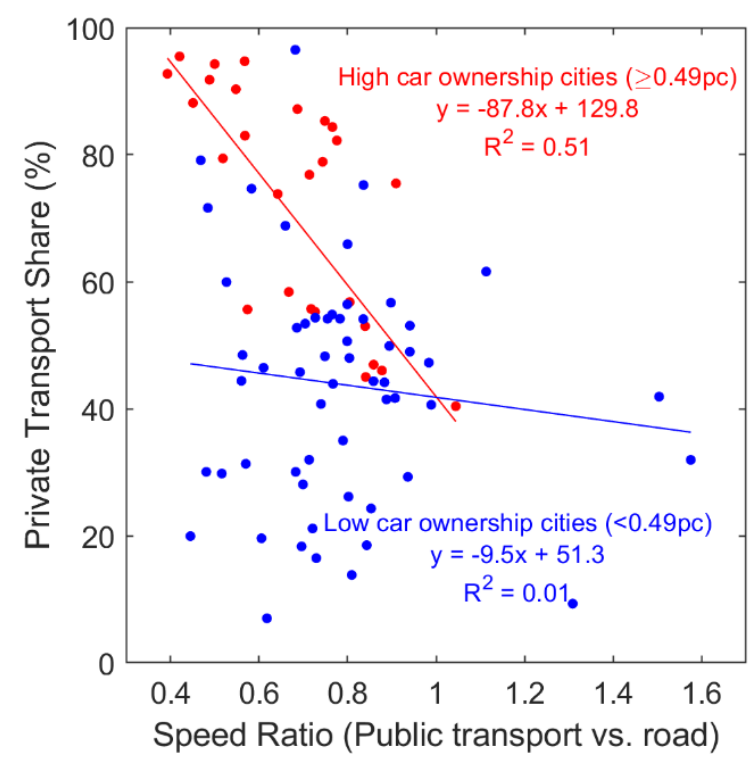

Figure 7: Private transport share vs. speed ratio (private transport vs. road), segmented by car ownership rate $(\mathbf{1 9 9 5 )}$

We found a similar negative association (not shown in Figure 7) between the private transport share and the ratio of investment in public transport and the road network in cities with high car ownership $\left(\mathrm{R}^{2}=0.45\right)$, but not in cities with low car ownership $\left(\mathrm{R}^{2}=0.003\right)$. These results suggest that the population in cities with high car ownership have the option to use their cars if public transport is unsatisfactory, while the population in cities with low car ownership is "forced" to use public transport regardless of its performance.

No strong relationships were found between the private transport share and the ratio of user costs for public transport and car trips $\left(\mathrm{R}^{2}\right.$ of 0.25 and 0.12 in low and high car ownership cities respectively).

\subsection{Land use}

The relationship between the private transport share and population density is negative and logarithmic (Figure 8). It has the strongest association $\left(\mathrm{R}^{2}=0.55\right)$ of all the non-segmented relationships between private transport share and other variables analysed in Section 4. This is consistent with the literature reviewed in Section 2.3. 


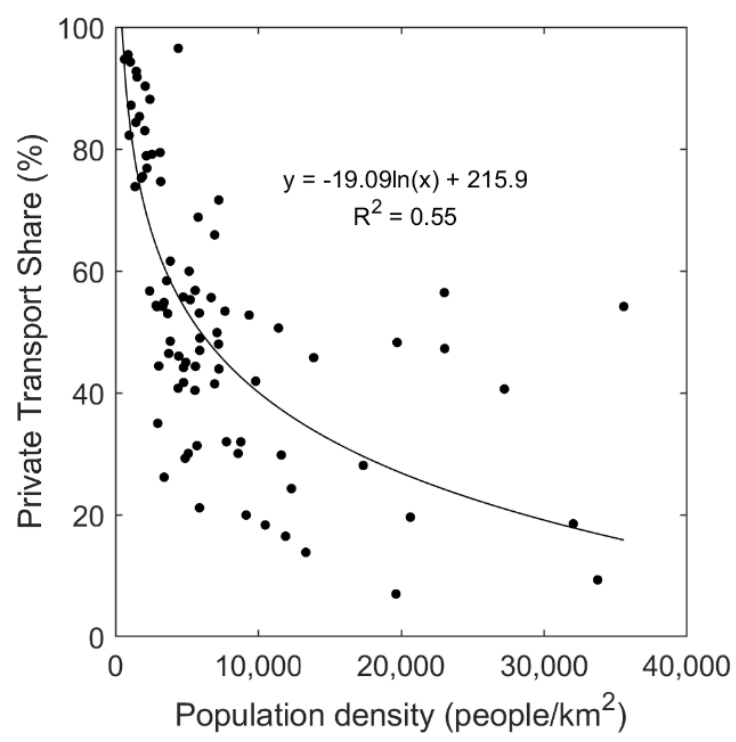

Figure 8: Private transport share vs. population density (1995)

However, when comparing 1995 and 2012 data, we found no apparent relationship between the changes in the private transport share and in population density among the 29 cities with data on both variables in both years. The private transport share decreased by a similar magnitude (-6.5\%) in cities where the population density decreased from 1995 to 2012 and in cities where the population density increased. This may be explained by the large representation of high-income European cities in this analysis (16 out of 29 cities), which showed a tendency to favour more sustainable transport modes in the last decades (see Section 1).

The relationship between private transport share and the proportion of jobs in the CBD (not shown in Figure 8) is also negative and logarithmic, although is weaker than the relationship with population density $\left(\mathrm{R}^{2}=0.26\right)$.

\section{Urban mobility transitions: cluster analysis}

\subsection{Cluster analysis of UITP 1995 data}

Cluster analysis was used to group cities with similar characteristics in terms of their private transport share and the 11 variables listed in Table 1. We used the K-means algorithm (MacQueen, 1967) in Stata SE15. The algorithm minimises the intra-cluster sum of squared Euclidean distances and maximizes the inter-cluster sum of squared Euclidean distances. The advantage of this method is allowing for the a-priori specification of the number of clusters. 
All variables were standardized (using Z-scores), to ensure that variables with a larger range do not dominate the classification. Solutions with three, four, and five clusters were produced. The three-cluster solution was selected because it provided a clearer interpretation in terms of the implicit pathways followed by cities of increasing income, as will be explained in the next subsection.

Table 2 shows the composition of the clusters. Table 3 shows, for each cluster, the means and standard deviations of the unstandardized variables, average distance from cluster centres, and average silhouette values. Figure 9 shows the means of the standardized variables in each cluster.

Table 2: Cluster membership for the three-cluster solution (1995)

\begin{tabular}{|c|c|c|c|c|c|c|}
\hline \multicolumn{7}{|c|}{ Cluster 1 ("Low motorisation") } \\
\hline Bangkok & Cairo & Curitiba & Ho Chi Minh City & Manila & Seoul & Tunis \\
\hline Beijing & Cape Town & Dakar & Hong Kong & Mumbai & Shanghai & \\
\hline Bogota & Chennai & Guangzhou & Jakarta & Prague & Taipei & \\
\hline Budapest & Cracow & Harare & Johannesburg & Sao Paulo & Tehran & \\
\hline \multicolumn{7}{|c|}{ Cluster 2 ("Car-based pathway") } \\
\hline Atlanta & Chicago & Los Angeles & Nantes & Riyadh & Toronto & \\
\hline Bologna & Denver & Manchester & Ottawa & San Diego & Vancouver & \\
\hline Brisbane & Houston & Melbourne & Perth & San Francisco & Washington & \\
\hline Calgary & Kuala Lumpur & Montreal & Phoenix & Tel Aviv & Wellington & \\
\hline \multicolumn{7}{|c|}{ Cluster 3 ("Sustainable pathway") } \\
\hline Amsterdam & Brussels & Glasgow & Lyon & New York & Rome & Stuttgart \\
\hline Athens & Copenhagen & Graz & Madrid & Newcastle & Ruhr & Sydney \\
\hline Barcelona & Dusseldorf & Hamburg & Marseille & Osaka & Sapporo & Tokyo \\
\hline Berlin & Frankfurt & Helsinki & Milan & Oslo & Singapore & Vienna \\
\hline Bern & Geneva & London & Munich & Paris & Stockholm & Zurich \\
\hline
\end{tabular}


Table 3: Cluster analysis of urban mobility variables (1995)

\begin{tabular}{lcccccc}
\hline & \multicolumn{2}{c}{ Cluster 1 } & \multicolumn{2}{c}{$\begin{array}{c}\text { Cluster 2 } \\
\text { "Car-based } \\
\text { pathway" }\end{array}$} & \multicolumn{2}{c}{$\begin{array}{c}\text { Cluster 3 } \\
\text { "Sustainable } \\
\text { pathway" }\end{array}$} \\
\hline & Mean & SD & Mean & SD & Mean & SD \\
\hline Private transport share & 31 & 14 & 81 & 12 & 50 & 10 \\
\hline GDP per capita (US\$) & 4676 & 4963 & 23417 & 8478 & 33139 & 11247 \\
Passenger cars per capita & 0.19 & 0.13 & 0.55 & 0.13 & 0.43 & 0.10 \\
\hline Length of freeways per capita (m) & 0.01 & 0.02 & 0.13 & 0.05 & 0.08 & 0.04 \\
Parking space per CBD job & 0.11 & 0.10 & 0.58 & 0.41 & 0.22 & 0.10 \\
\hline Length of reserved PT routes per capita (m) & 0.04 & 0.06 & 0.07 & 0.08 & 0.19 & 0.15 \\
Public transport seat-km of service per capita & 3411 & 2346 & 1882 & 996 & 4533 & 2269 \\
\hline Investment ratio (PT vs. road) & 1.53 & 3.28 & 0.26 & 0.17 & 0.84 & 0.79 \\
Speed ratio (PT vs. road) & 0.76 & 0.18 & 0.59 & 0.12 & 0.85 & 0.21 \\
Cost ratio (PT vs. car, per passenger-km) & 0.18 & 0.18 & 0.40 & 0.21 & 0.37 & 0.19 \\
\hline Population density (people/km $\left.{ }^{2}\right)$ & 14656 & 9830 & 2694 & 1875 & 5691 & 3188 \\
Proportion of jobs in the CBD (\%) & 22 & 17 & 12 & 6 & 20 & 9 \\
\hline Average distance from cluster centres & & & & & & \\
$\quad$ Cluster 1 & 2.9 & & 4.9 & & 3.9 & \\
$\quad$ Cluster 2 & 5.5 & & 2.1 & & 3.8 & \\
$\quad$ Cluster 3 & 4.7 & & 3.8 & & 2.5 & \\
\hline Average silhouette value & 0.39 & & 0.41 & & 0.33 & \\
\hline Number of observations & 24 & & 24 & & 35 & \\
\hline
\end{tabular}

Notes: PT: Public transport; CBD: Central Business District; SD: Standard deviation

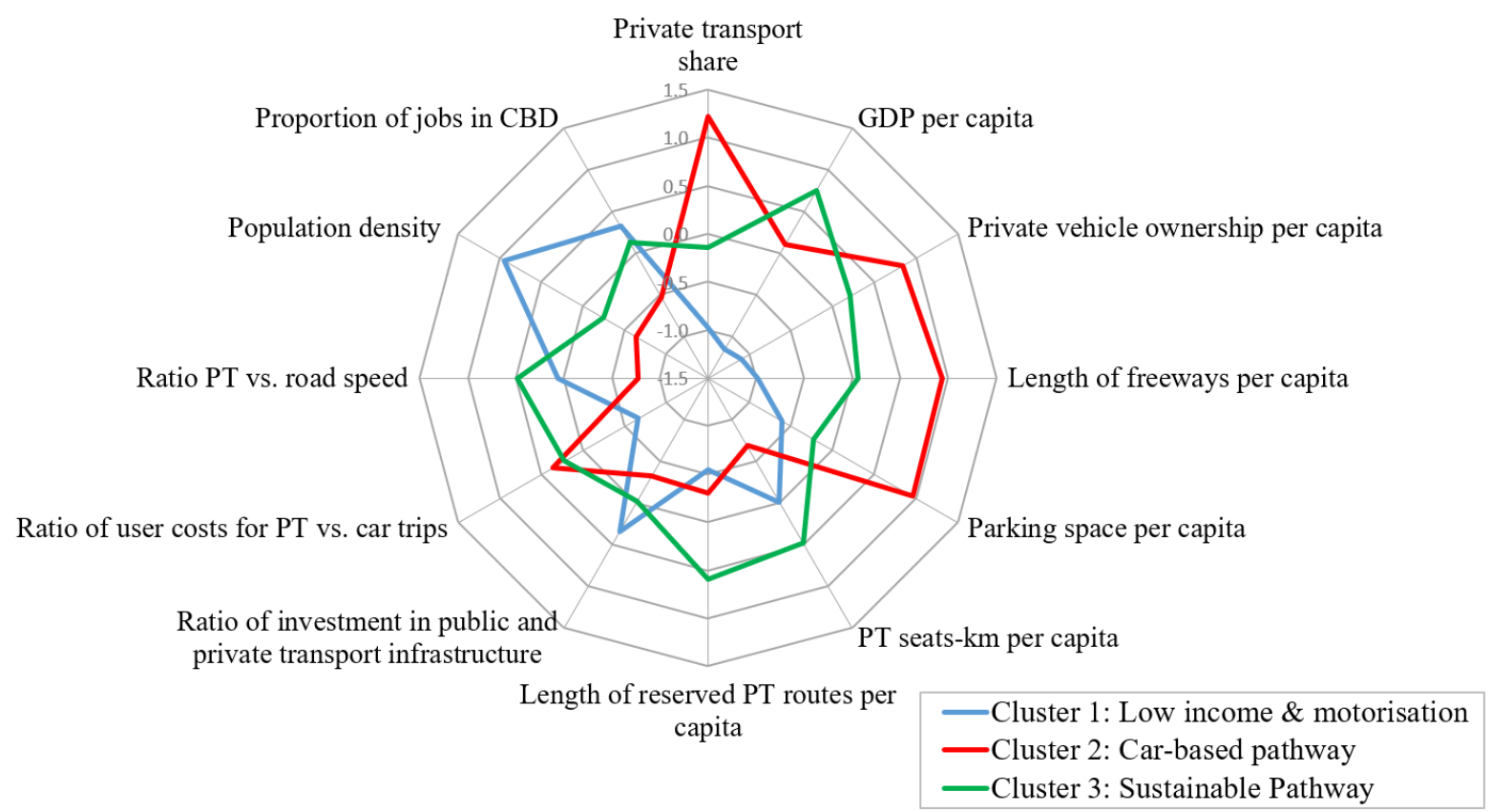

Figure 9: Average normalised values by cluster (1995)

Cluster 1 (labelled "low motorisation") contains mostly cities in developing countries, with low income (compared to other clusters), low car ownership, and low private transport share. This cluster has the highest population density of the three clusters; the lowest supply of 
freeways, parking spaces, and reserved public transport routes; and the lowest relative cost of public transport use compared with car travel.

There are two clusters of high-income cities. Cluster 2 (labelled "car-based pathway") contains cities mostly in North America and Oceania. This cluster has both high car ownership and private transport share. It also has the highest supply of freeways and parking spaces of the three clusters; the lowest supply of public transport seat-km; the lowest ratio of investment in public transport vs. road and the lowest ratio of public transport vs. road speeds. It also has the lowest population density and proportion of jobs in the CBD.

Cluster 3 (labelled "sustainable pathway") contains mostly Western European cities and has a considerably lower private transport share and car ownership rate, compared with Cluster 2, despite having higher income per capita. This cluster also has the highest public transport seat-km of service per capita of all three clusters, and the highest length of reserved public transport routes per capita and ratio of public transport vs. road speed. The average population density and proportion of jobs in the CBD of Cluster 3 are higher than Cluster 2 (shown in Table 3).

As shown in Table 3, the average distance from each city to its own cluster centre is much smaller than the distance to the other cluster centres. The average silhouette values $(0.39$, 0.41 , and 0.33 for Clusters 1,2 , and 3 respectively) are also acceptable.

Some of the cities that have larger distances to their own cluster centres in the three-cluster solution form their own cluster if a four or five-cluster solution is specified (not shown in the tables or figure in this section). For example, German, Swiss, and Scandinavian cities split from Cluster 3 in the four-cluster solution. These cities have similar private transport shares as the rest of Cluster 3 but higher income, length of freeways per capita, public transport seat$\mathrm{km}$, and reserved public transport routes per capita. In the five-cluster solution, some Asian cities split from Cluster 1: these cities have lower private transport shares, higher ratios of public transport vs. road speed, a lower proportion of jobs in the CBD, and much higher population densities relative to other Cluster 1 cities.

\subsection{Using clusters to identify potential pathways for cities}

If we estimate separate trendlines for Clusters 1 and 2, and for Clusters 1 and 3 in Figure 3 (which shows private transport share versus GDP per capita), we can identify distinct pathways for the private transport share as cities grow in income. Figure 10 shows a 
bifurcation point where the private transport share branches out into two distinct pathways. The first is a transition from Cluster 1 to 2 , i.e. an increase in the private transport share to around $80 \%$. The other is a transition from Cluster 1 to 3 , i.e. the stabilisation of the private transport share at around 50\% and an eventual decline. The figure also shows that the average level of GDP per capita at which the private transport share peaks is approximately the same for cities in Clusters 2 and 3 (around US\$ 30,000), the difference being the level of the private transport share at which it occurs.

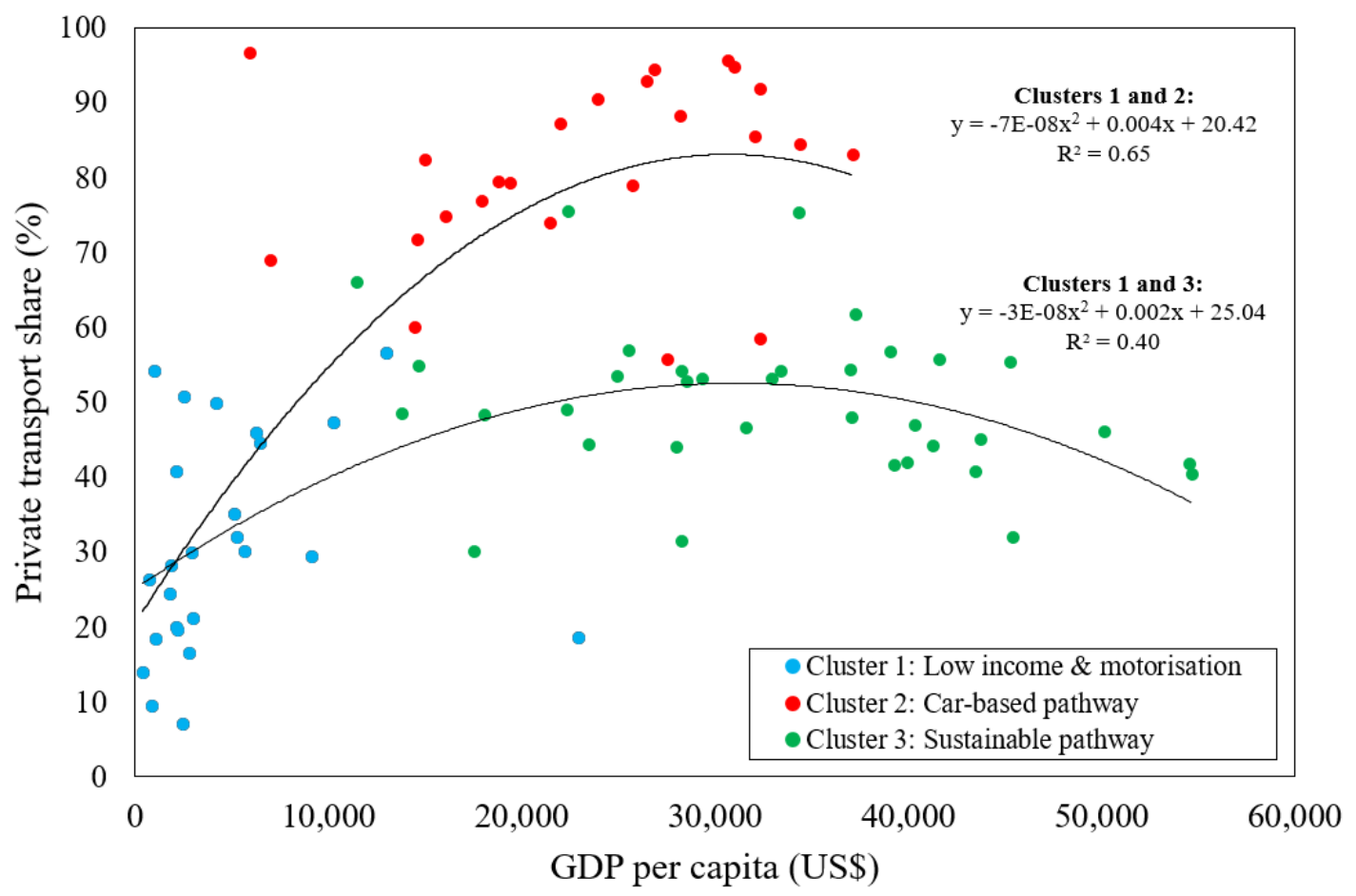

Figure 10: Private transport share vs. GDP per capita, segmented by cluster (1995)

These results suggest that the cities in developing countries that prioritise the supply and quality of private transport, as well as low-density and decentralised land use patterns (characteristics of Cluster 2) are more likely to transition from Cluster 1 to Cluster 2 and increase their private transport share. Conversely, cities that prioritise the supply and quality of public transport, as well as high-density and centralised land uses (characteristics of Cluster 3), are more likely to transition from Cluster 1 to Cluster 3 and stabilize and eventually reduce the private transport share.

\subsection{Validation using UITP 2012 data}

The hypothesis that cities can follow two distinct pathways, implicit in the 1995 crosssectional patterns in Figure 10, can be validated by the observed evolution of selected cities 
since 1995 . We performed this analysis on 14 cities that have data on private transport share and GDP per capita in both the UITP 1995 and 2012 datasets. This includes three Cluster 1 cities, two Cluster 2 cities, and nine Cluster 3 cities. To ensure that the two datasets were comparable, the GDP per capita values in the UITP 2012 dataset (originally in Euros) were first converted to US\$ using Purchasing Power Parity data from the Organisation for Economic Cooperation and Development (OECD, 2016). The values were then adjusted to real values using an annual average inflation rate of $2.2 \%$ (US BLS, 2018).

Figure 11 shows that the private transport share generally followed one of the two pathways identified in the cross-sectional data.

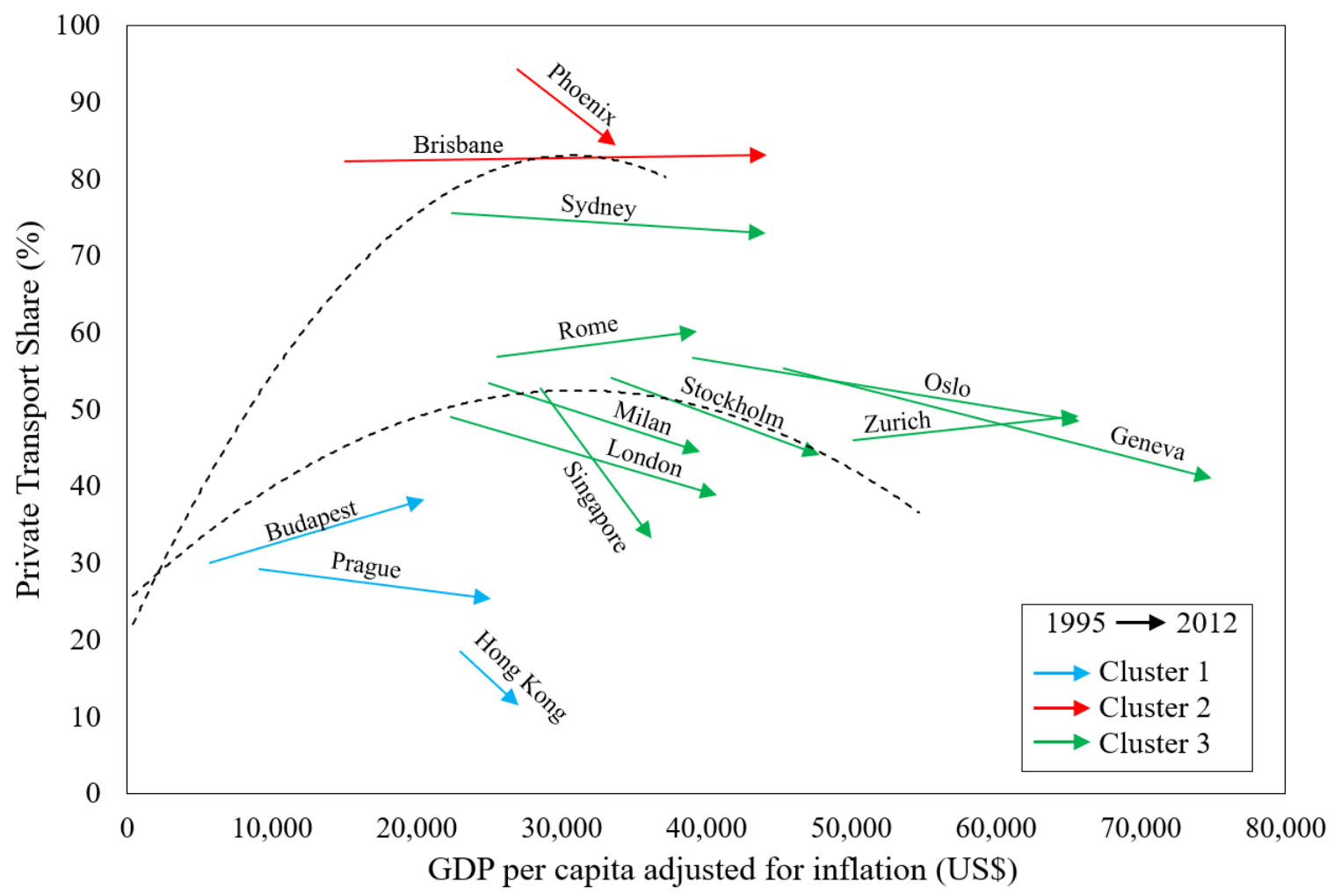

Figure 11: Cluster membership vs. evolution of GDP per capita and private transport share (1995-2012)

Among Cluster 1 cities, Budapest and Prague appear to have followed the pathway towards Cluster 3. In Budapest, the private transport share increased moderately from $30 \%$ to $38 \%$, which is consistent with the characteristics of Cluster 3. In Prague, the private transport share decreased from $29 \%$ to $25 \%$, which suggests a decoupling between the private transport share and income sooner than the peak identified in the 1995 pathways (i.e. around US\$30,000 and $50 \%$ private transport share). This supports the hypothesis advanced in recent literature that some cites in Eastern Europe, Asian, and Latin America are reducing the private transport share sooner than cities in Western Europe did in the past (Kenworthy et al., 2017). As shown 
in Figure 11, this pattern also applies to the case of Hong Kong, with the caveat that this city is relatively distant from the other cities in its cluster (Cluster 1), and as such, it may follow a completely different pathway.

The evolution of the two Cluster 2 cities (Brisbane and Phoenix) from 1995 to 2012 is also consistent with the relationship identified in the 1995 cross-sectional data, which suggests the private transport share in Cluster 2 cities peaks when GDP per capita is around US\$30,000. Almost all the cities in Cluster 3 experienced a reduction in the private transport share from 1995 to 2012, following closely the pathway implicit in the 1995 cross-sectional patterns.

\section{Explaining differences in car use across cities: regression analysis}

A regression analysis was conducted to test the statistical significance of the 11 variables listed in Table 1 as predictors of the private transport share. Six models were estimated. Model 1 used the whole dataset of 84 cities. Models 2, 3 and 4 were estimated separately on the three clusters generated in the previous analysis. Models 5 and 6 were estimated for pairs of clusters $(1+2$ and $1+3)$ that correspond to the two pathways shown in Figure 10 .

The model specification was based on the results of Section 4, which showed that several of the associations between the private transport share and the explanatory variables were nonlinear or varied within segments of the sample. We therefore used three types of functional transformation for the explanatory variables (linear, logarithmic, and quadratic) and several interactions between explanatory variables (with one variable defining the segments). Model selection was based on statistical significance (retaining variables significant at least at the $10 \%$ level) and multicollinearity tests (using variance inflation factors). No patterns were observed in the variance of prediction errors when plotting the residual vs. predicted values of the dependent variable, which suggests the absence of heteroscedasticity. Table 4 shows the estimated models. 
Table 4: Regression models of the proportion of trips made by private motorised modes (1995)

\begin{tabular}{|c|c|c|c|c|c|c|c|c|c|c|c|c|}
\hline & \multirow{2}{*}{\multicolumn{2}{|c|}{$\begin{array}{c}\text { Model 1 } \\
\text { Full dataset }\end{array}$}} & \multirow{2}{*}{\multicolumn{2}{|c|}{$\begin{array}{l}\text { Model } 2 \\
\text { Cluster } 1\end{array}$}} & \multirow{2}{*}{\multicolumn{2}{|c|}{$\begin{array}{l}\text { Model } 3 \\
\text { Cluster } 2 \\
\end{array}$}} & \multirow{2}{*}{\multicolumn{2}{|c|}{$\begin{array}{l}\text { Model } 4 \\
\text { Cluster } 3\end{array}$}} & \multirow{2}{*}{\multicolumn{2}{|c|}{$\frac{\text { Model } 5}{\text { Cluster } 1+2}$}} & \multicolumn{2}{|c|}{ Model 6} \\
\hline & & & & & & & & & & & Clus & $1+3$ \\
\hline & Coef. & $S E$ & Coef. & $S E$ & Coef. & $S E$ & Coef. & $S E$ & Coef. & $S E$ & Coef. & $S E$ \\
\hline Constant & 164 & $26.5^{* * *}$ & 86.5 & $18.7^{* * *}$ & 192 & $16.8^{* * *}$ & 166 & $25.4^{* * *}$ & 144 & $32.2^{* * *}$ & 149 & $30.3^{* * *}$ \\
\hline$\left(10^{-3}\right)$ GDP per capita & 1.27 & $0.30^{* * *}$ & 5.05 & $1.18^{* * *}$ & - & - & -0.30 & $0.12^{* *}$ & 1.88 & $0.68^{* * *}$ & 0.96 & $0.34^{* * * *}$ \\
\hline$\left(10^{-6}\right)$ GDP per capita ${ }^{2}$ & -0.02 & $0.01^{* * *}$ & -0.24 & $0.05^{* * *}$ & - & - & - & - & -0.04 & $0.02^{* *}$ & -0.02 & $0.01^{* * *}$ \\
\hline LOG (Passenger cars per capita) & - & - & - & - & - & - & - & - & 6.02 & $2.80^{* *}$ & 6.72 & $2.35^{* * *}$ \\
\hline $\begin{array}{l}\text { Passenger cars per capita * Low population } \\
\text { density }\end{array}$ & 29.1 & $8.05^{* * *}$ & - & - & - & - & - & - & - & - & - & - \\
\hline Length of freeways per capita & - & - & 331 & $157^{*}$ & - & - & - & - & 95.2 & $43.3^{* *}$ & - & - \\
\hline LOG(Parking spaces per CBD job) & - & - & - & - & - & - & - & - & - & - & - & - \\
\hline Length of reserved PT routes per capita & - & - & -105 & $36.5^{* *}$ & -41.2 & $17.5^{* *}$ & - & - & - & - & - & \\
\hline LOG (PT seat-km per capita) & -7.33 & $1.58^{* * *}$ & -4.25 & $2.28^{* *}$ & - & - & - & - & -5.96 & $2.21^{* *}$ & -4.72 & $2.03^{* *}$ \\
\hline LOG (Investment ratio: PT vs. road) & - & - & - & - & -2.83 & $1.51^{*}$ & - & - & - & - & - & - \\
\hline Speed ratio: PT vs. road & - & - & - & - & - & - & - & - & - & - & - & - \\
\hline LOG (User cost ratio: PT vs. car) & 6.03 & $1.80^{* * *}$ & - & - & 8.96 & $3.17^{* *}$ & - & - & 7.93 & $2.13^{* * *}$ & 3.79 & $1.87^{* *}$ \\
\hline LOG (Population density) & -5.66 & $2.44^{* *}$ & - & - & -13.5 & $2.03^{* * *}$ & -12.5 & $2.89^{* * *}$ & -4.89 & $2.62^{*}$ & -4.79 & $2.27^{* *}$ \\
\hline LOG (\% jobs in the CBD) & -4.83 & $2.25^{* *}$ & -12.2 & $3.04^{* * * *}$ & - & - & - & - & - & - & -6.33 & $2.49^{* *}$ \\
\hline $\mathrm{N}$ & & 4 & & & & & & & & & & \\
\hline Adjusted $\mathrm{R}^{2}$ & & 80 & & & & & & & & & & \\
\hline
\end{tabular}

Notes: Significance levels: ${ }^{* * *} 1 \%,{ }^{* *} 5 \%,{ }^{*} 10 \%$; "-": variable not significant at $10 \%$ level in preliminary runs of the models and excluded from the final model. PT:

Public transport, CBD: Central Business District, Coef.: Coefficient, SE: Standard error. 
The model for the overall sample (Model 1) has a good fit $\left(\mathrm{R}^{2}=0.80\right)$ and the coefficients are precisely estimated with small standard errors. All final variables are significant at the $1 \%$ level, except population density and proportion of jobs in the CBD, which are significant at the 5\% level. The results broadly confirm the analysis in Section 4. The GDP per capita coefficient is positive, and the squared GDP per capita coefficient is negative. This confirms the quadratic relationship found in Section 4.1 between the private transport share and GDP per capita. The private transport share is positively associated with car ownership in cities with low density $\left(<3500\right.$ people $\left./ \mathrm{km}^{2}\right)$ and with the ratio of public transport and car user costs. It is negatively associated with the public transport seat-km of service per capita, population density, and proportion of jobs in the CBD.

Despite the bivariate association between the two variables, as previously shown in Figure 5, the indicators of provision for private transport (length of freeways per capita and parking spaces per CBD job) are not significant at the $10 \%$ level when controlling for other variables, and were thus excluded from Model 1. The length of the reserved public transport routes per capita, investment ratio, and speed ratio are also not significant.

In Cluster 1 (Model 2), the private transport share has a quadratic association with GDP per capita. However, in Cluster 2 (Model 3) there is no significant association between these two variables, suggesting that in this cluster the growth in private transport share is decoupled from income growth and is explained by other factors. In Cluster 3 (Model 4), the association is negative, i.e. the private transport share decreases with income. This may be explained by changes in lifestyles, education and attitudes, as mentioned at the end of Subsection 2.1.

With regards to transport-related variables, in Cluster 1 the private transport share depends positively on the length of freeways, and negatively on public transport seat-km and length of reserved public transport routes per capita. This confirms the importance of these variables as cities start to develop their transport systems during the first stages of economic growth. In Cluster 2, the private transport share depends negatively on the length of reserved public transport routes and relative investment on public transport vs. road, and positively on the relative user cost between public transport and car travel. In Cluster 3, no transport variables are significant. Land use factors are significant in all clusters: the private transport share is negatively associated with population density in clusters 2 and 3 and with the proportion of jobs in the CBD in Cluster 1. 
The model for Cluster 3 has an $\mathrm{R}^{2}$ of only 0.38 , considerably lower than the $\mathrm{R}^{2}$ in the models for the other clusters. This suggests that a substantial part of the differences in the private transport share within Cluster 3 cities are explained by factors other than the socio-economic, transport, and land use variables included in the model. An example of those factors is the quality of the infrastructure for pedestrians and cyclists, which, as mentioned in Section 3, was not included in our analyses due to data limitations.

In the models of the two possible pathways (Models 5 and 6), the private transport share depends on almost the same set of variables as Model 1, including income, car ownership, public transport seat-km per capita, user cost ratio, and population density. In Model 5 (Clusters 1+2), it also depends (positively) on the length of freeways per capita.

\section{Conclusions and policy implications}

This paper explored the relationships between the private transport share at the city level and various socio-economic, transport, and land use variables. We used the 1995 UITP Millennium Cities dataset to estimate cross-sectional relationships, and the smaller 2012 UITP Mobility in Cities database to confirm, where possible, if the evolution of cities between 1995 and 2012 is consistent with the 1995 relationships. Segmented bivariate analysis showed that the relationships between the private transport share and other variables are in many cases non-linear or mediated by a third variable. K-means cluster analysis then showed that cities tend to branch out into two distinct pathways as they increase in wealth: cities either increase their private transport share to around $80 \%$, or stabilize the private transport share at around 50\% and eventually reduce it (Figures 10 and 11). Regression analysis provided further evidence on the variables associated with the two pathways.

The relatively small sample of cities limited our ability to estimate relationships that are more robust, and to confirm these relationships looking at the evolution since 1995. In addition, city-level relationships may mask internal variations within each city. For example, newer and more peripheral areas typically have a higher private share than older and more central areas. Despite these limitations, the different statistical techniques used in this paper all point to the same general conclusion, where income is not the sole determinant of the private transport share, i.e. it is not inevitable that cities increase their private transport share as they become wealthier. 
We found consistent evidence that the private transport share is related to aspects such as the provision, quality, and cost of public transport, in absolute terms or relative to private transport. The implication is that cities that prioritise these aspects are more likely to contain their private transport share. However, as noted below, the particular type of transport policies that might be effective in each city depends on the existing income level, car ownership, and urban density.

For example, the private transport share is more strongly associated with the provision for public transport (as measured by seat-km of service per capita and the length of reserved public transport routes) in lower-density cities (Figure 6), and in the cities in developing countries that were grouped in Cluster 1 (Model 2 in Table 4). To reduce the private transport share, these cities can apply policies such as (i) the construction of new rail, tram, metro, or bus rapid transit systems; (ii) road designs that prioritise public transport (e.g. dedicated bus lanes); (iii) public provision of bus and other public transport services; and (iv) subsidies for private operators to increase capacity.

Similar considerations can be made about public transport quality and cost. As shown in Figure 7 and Model 3 in Table 4, the private transport share is more strongly related to the relative investment, speed, and cost of public transport in high car ownership cities, i.e. those in Cluster 2. To reduce the private transport share, these cities can: (i) improve the relative door-to-door speeds by public transport; (ii) increase subsidies for public transport operators to reduce fares; and (iii) apply policies such as congestion charging to increase the cost of operating a private vehicle and account for its negative externalities on society.

It is also clear from the results that land use policies are an essential complement of transport policies. Policies to increase population density may facilitate the reduction in the private transport share, with our results pointing to both a direct effect possibly explained by reducing trips distances and improving the financial viability of public transport (Figure 8), and an indirect effect via the decoupling of relationships between car ownership and its use (Figure 4). However, while we found cross-sectional relationships between population density and the private transport share, there was no evidence that these relationships apply over time, possibly due to the much weaker representation of cities from different regions in the 2012 dataset.

Overall, our results suggest that a combination of different transport and land use policies may help cities in developing countries to contain the private transport share as they increase 
in wealth. Nevertheless, we highlight the importance to continue documenting the evolution of private transport shares in the three clusters of cities. For example, future work could use the next edition of the UITP dataset, scheduled to be released in 2020, to assess: (i) the possibility for Cluster 2 cities to reduce their private transport share and transition to Cluster 3; and (ii) the effect of new modes of transport, such as ride-sharing, on the private transport share

\section{References}

Ahmad, S., \& Oliveira, J. A. (2016). Determinants of urban mobility in India: Lessons for promoting sustainable and inclusive urban transportation in developing countries. Transport Policy, 50, 106-114. https://doi.org/10.1016/J.TRANPOL.2016.04.014

Alotaibi, O., \& Potoglou, D. (2017). Perspectives of travel strategies in light of the new metro and bus networks in Riyadh City, Saudi Arabia. Transportation Planning and Technology, 40(1), 4-27. https://doi.org/10.1080/03081060.2016.1238572

Banister, D. (2011). Cities, mobility and climate change. Journal of Transport Geography, 19(6), 1538-1546. https://doi.org/10.1016/J.JTRANGEO.2011.03.009

Basso, L. J., \& Silva, H. E. (2014). Efficiency and substitutability of transit subsidies and other urban transport policies. American Economic Journal: Economic Policy, 6(4), 1-33. https://doi.org/10.1257/pol.6.4.1

Briggs, M., Webb, J., \& Wilson, C. (2015). Automotive modal lock-in: The role of path dependence and large socio-economic regimes in market failure. Economic Analysis and Policy, 45, 58-68. https://doi.org/http://dx.doi.org/10.1016/j.eap.2015.01.005

Buehler, R. (2009). Determinants of automobile use - comparison of Germany and the United States.

Transportation Research Record: Journal of the Transportation Research Board, 2139(1), 161-171. https://doi.org/10.3141/2139-19

Buehler, R. (2011). Determinants of transport mode choice: a comparison of Germany and the USA. Journal of Transport Geography, 19(4), 644-657. https://doi.org/10.1016/J.JTRANGEO.2010.07.005

Buehler, R., Pucher, J., Gerike, R., \& Götschi, T. (2017). Reducing car dependence in the heart of Europe: lessons from Germany, Austria, and Switzerland. Transport Reviews, 37(1), 1-25. https://doi.org/10.1080/01441647.2016.1177799

Cameron, I., Kenworthy, J. R., \& Lyons, T. J. (2003). Understanding and predicting private motorised urban mobility. Transportation Research Part D: Transport and Environment, 8(4), 267-283. https://doi.org/10.1016/S1361-9209(03)00003-8

Cameron, I., Lyons, T. ., \& Kenworthy, J. . (2004). Trends in vehicle kilometres of travel in world cities, 19601990: underlying drivers and policy responses. Transport Policy, 11(3), 287-298. https://doi.org/10.1016/J.TRANPOL.2004.01.002

Cervero, R. (2003). Road expansion, urban growth, and induced travel: a path analysis. Journal of the American Planning Association, 69(2), 145-163. https://doi.org/10.1080/01944360308976303 
Cullinane, S. (2002). The relationship between car ownership and public transport provision: a case study of Hong Kong. Transport Policy, 9(1), 29-39. https://doi.org/10.1016/S0967-070X(01)00028-2

Dargay, J., \& Gately, D. (1999). Income's effect on car and vehicle ownership, worldwide: 1960-2015.

Transportation Research Part A: Policy and Practice, 33(2), 101-138. https://doi.org/10.1016/S09658564(98)00026-3

Delbosc, A., \& Currie, G. (2013). Causes of youth licensing decline: A synthesis of evidence. Transport Reviews, 33(3), 271-290. https://doi.org/10.1080/01441647.2013.801929

Garikapati, V. M., Pendyala, R. M., Morris, E. A., Mokhtarian, P. L., \& McDonald, N. (2016). Activity patterns, time use, and travel of millennials: a generation in transition? Transport Reviews, 36(5), 558-584. https://doi.org/10.1080/01441647.2016.1197337

Goodwin, P., \& Van Dender, K. (2013). 'Peak Car' — Themes and Issues. Transport Reviews, 33(3), $243-254$. https://doi.org/10.1080/01441647.2013.804133

Gössling, S. (2013). Urban transport transitions: Copenhagen, city of cyclists. Journal of Transport Geography, 33, 196-206. https://doi.org/http://dx.doi.org/10.1016/j.jtrangeo.2013.10.013

Guerra, E., \& Cervero, R. (2011). Cost of a ride. The effects of densities on fixed-guideway transit ridership and costs. Journal of the American Planning Association, 77(3), 267-290. https://doi.org/10.1080/01944363.2011.589767

Halpern, C., Persico, S., Orlandi, C., \& Vergara, M. (2018). Transport Policy Developments: Western European Cross-city comparisons. CREATE Project Deliverable 4.3. Retrieved from http://nws.eurocities.eu/MediaShell/GetMediaBytes?mediaReference=id173988

Han, S. S. (2010). Managing motorization in sustainable transport planning: the Singapore experience. Journal of Transport Geography, 18(2), 314-321.

Harrington, W., \& McConnell, V. (2003). Motor Vehicles and the Environment. Washington, DC: Resources for the Future.

Hopkins, D. (2016). Can environmental awareness explain declining preference for car-based mobility amongst generation Y? A qualitative examination of learn to drive behaviours. Transportation Research Part A: Policy and Practice, 94, 149-163. https://doi.org/10.1016/J.TRA.2016.08.028

Illich, I. (1974). Energy and equity. New York: Harper and Row.

Ingvardson, J. B., \& Nielsen, O. A. (2018). How urban density, network topology and socio-economy influence public transport ridership: Empirical evidence from 48 European metropolitan areas. Journal of Transport Geography, 72, 50-63. https://doi.org/10.1016/J.JTRANGEO.2018.07.002

ITF (2013). Long-run Trends in Car Use. Roundtable Report 152 (ITF Round Tables). Paris: OECD.

Jones, P., Anciaes, P., Buckingham, C., Cavoli, C., Cohen, T., Cristea, L., Gerike, R., Halpern, C., Pickup, L. (2018). Urban Mobility: Preparing for the Future, Learning from the Past. CREATE Project. Retrieved from http://nws.eurocities.eu/MediaShell/GetMediaBytes?mediaReference=id173997

Karathodorou, N., Graham, D. J., \& Noland, R. B. (2010). Estimating the effect of urban density on fuel demand. Energy Economics, 32(1), 86-92. https://doi.org/10.1016/J.ENECO.2009.05.005

Kenworthy, J. (2014). Total daily mobility patterns and their policy implications for forty-three global cities in 1995 and 2005. World Transport Policy \& Practice, 20(1), 41-55.

Kenworthy, J., Kenworthy, \& R., J. (2017). Is automobile dependence in emerging cities an irresistible force? 
Perspectives from São Paulo, Taipei, Prague, Mumbai, Shanghai, Beijing, and Guangzhou. Sustainability, 9(11), 1953. https://doi.org/10.3390/su9111953

Kenworthy, J., \& Laube, F. (2001). UITP Millennium Cities Database for Sustainable Transport (CDDatabase). Brussels: International Association of Public Transport (UITP).

Kenworthy, J., \& Laube, F. (2002a). Travel demand management: the potential for enhancing urban rail opportunities \& reducing automobile dependence in cities. World Transport Policy \& Practice, 8(3), 20 36.

Kenworthy, J., \& Laube, F. (2002b). Urban transport patterns in a global sample of cities \& their linkages to transport infrastructure, land use, economics \& environment. World Transport Policy \& Practice, 8(3), 5 19.

Kenworthy, J. R., \& Laube, F. B. (1999). Patterns of automobile dependence in cities: an international overview of key physical and economic dimensions with some implications for urban policy. Transportation Research Part A: Policy and Practice, 33(7-8), 691-723. https://doi.org/10.1016/S0965-8564(99)00006-3

Li, J., Walker, J. L., Srinivasan, S., \& Anderson, W. P. (2010). Modeling private car ownership in China investigation of urban form impact across megacities. Transportation Research Record: Journal of the Transportation Research Board, 2193(1), 76-84. https://doi.org/10.3141/2193-10

MacQueen, J. (1967). Some methods for classification and analysis of multivariate observations. In Proceedings of the Fifth Berkeley Symposium on Mathematical Statistics and Probability Vol.1. Berkeley: University of California Press., pp. 281-297.

McIntosh, J., Trubka, R., Kenworthy, J., \& Newman, P. (2014). The role of urban form and transit in city car dependence: Analysis of 26 global cities from 1960 to 2000. Transportation Research Part D: Transport and Environment, 33, 95-110. https://doi.org/http://dx.doi.org/10.1016/j.trd.2014.08.013

Metz, D. (2013). Peak car and beyond: The fourth era of travel. Transport Reviews, 33(3), 255-270. https://doi.org/10.1080/01441647.2013.800615

Newman, P. G., \& Kenworthy, J. R. (1989). Cities and Automobile Dependence: An International Sourcebook. Aldershot: Gower.

Newman, P., \& Kenworthy, J. (1999). Sustainability and Cities: Overcoming Automobile Dependence. Washington DC: Island Press

Newman, P., \& Kenworthy, J. (2015). The End of Automobile Dependence. Washington DC: Island Press.

Nicolopoulou-Stamati, P., Hens, L., \& Howard, V. (2005). Environmental Health Impacts of Transport and Mobility. Dordrecht:Springer.

Noland, R. B., \& Lem, L. L. (2002). A review of the evidence for induced travel and changes in transportation and environmental policy in the US and the UK. Transportation Research Part D: Transport and Environment, 7(1), 1-26.

OECD (2016). Purchasing Power Parities (PPP) - OECD Data. Retrieved from https://data.oecd.org/conversion/purchasing-power-parities-ppp.htm

Pojani, D., \& Stead, D. (Eds.). (2017). The Urban Transport Crisis in Emerging Economies. Cham: Springer International Publishing.

Santos, G., Maoh, H., Potoglou, D., \& von Brunn, T. (2013). Factors influencing modal split of commuting journeys in medium-size European cities. Journal of Transport Geography, 30, 127-137. 
https://doi.org/10.1016/J.JTRANGEO.2013.04.005

Schafer, A. (1998). The global demand for motorized mobility. Transportation Research Part A: Policy and Practice, 32(6), 455-477. https://doi.org/10.1016/S0965-8564(98)00004-4

Schwanen, T. (2002). Urban form and commuting behaviour: a cross-European perspective. Tijdschrift voor Economische en Sociale Geografie, 93(3), 336-343. https://doi.org/10.1111/1467-9663.00206

Tiwari, G., Jain, D., \& Ramachandra Rao, K. (2016). Impact of public transport and non-motorized transport infrastructure on travel mode shares, energy, emissions and safety: Case of Indian cities. Transportation Research Part D: Transport and Environment, 44, 277-291. https://doi.org/10.1016/J.TRD.2015.11.004

US BLS (2018). U.S. Bureau of Labor Statistics Consumer Price Index (CPI). Retrieved from https://www.bls.gov/cpi/

Van Acker, V., \& Witlox, F. (2010). Car ownership as a mediating variable in car travel behaviour research using a structural equation modelling approach to identify its dual relationship. Journal of Transport Geography, 18(1), 65-74. https://doi.org/10.1016/J.JTRANGEO.2009.05.006

Van de Coevering, P., \& Schwanen, T. (2006). Re-evaluating the impact of urban form on travel patterns in Europe and North-America. Transport Policy, 13(3), 229-239. https://doi.org/10.1016/J.TRANPOL.2005.10.001

World Bank (1997) World Development Indicators. World Bank, Washington. Retrieved from http://documents.worldbank.org/curated/en/615561468766151166/World-development-indicators-1997 Younes, B. (1995). The benefits of improving public transport: a myth or reality? Transport Reviews, 15(4), $333-356$. 